J.Natn.Sci.Foundation Sri Lanka 201442 (2): 101-110

DOI: http://dx.doi.org/10.4038/jnsfsr.v42i2.6994

RESEARCH ARTICLE

\title{
Pre-harvest chemical elicitor treatment enhances induced resistance in harvested banana fruit cv. 'Embul' and reduces anthracnose caused by Colletotrichum musae
}

\author{
U.W.N.P. Wanigasekara, N.K.B. Adikaram* and C.L. Abayasekara \\ Department of Botany, Faculty of Science, University of Peradeniya, Peradeniya.
}

Revised: 07 November 2013; Accepted: 29 January 2014

\begin{abstract}
Developing banana fruits cv. 'Embul' were treated in the field with chemical elicitors, Bion ${ }^{\circledR}$, salicylic acid (SA) or $\mathrm{K}_{2} \mathrm{HPO}_{4}$ at two stages, 2 and 4 or 9 and 11 weeks after bunch emergence. Fruits harvested $14-15$ weeks after bunch emergence were inoculated with Colletotrichum musae, and the development of anthracnose was assessed during ripening. Treatment with Bion ${ }^{\circledR}$ or SA at 9 and 11 weeks after bunch emergence while delaying the disease incidence significantly reduced $(\mathrm{p}<0.05)$ the severity of the disease by $43 \%$ and $65 \%$, respectively compared to the control. SA $(500 \mathrm{mg} / \mathrm{L})$ treatment was $22 \%$ more effective than Bion ${ }^{\circledR}(200 \mathrm{mg} / \mathrm{L})$ while the treatment with $\mathrm{K}_{2} \mathrm{HPO}_{4}(20 \mathrm{mg} / \mathrm{L})$ increased the disease severity by $5 \%$. Bion ${ }^{\circledR}$ or SA-treated fruits when challenge inoculated with $C$. musae after harvest showed a significantly enhanced chitinase activity $(p<0.05)$. There was also an increased $\beta-1,3$-glucanase activity and antifungal activity of the fruit peel compared to the controls. The elicitor treatment did not affect the fruit weight or postharvest quality.
\end{abstract}

Keywords: $\beta$-1,3-glucanase, chemical elicitors, chitinase, induced defense.

\section{INTRODUCTION}

Anthracnose caused by Colletotrichum musae (Berk. \& Curt.) v. Arx is by far the most destructive postharvest disease in all banana producing and marketing countries in the world. The fungus infects the young developing fruit in the field and remains quiescent until the fruit approaches maturity and ripening (Swinburne, 1983). The fungi causing quiescent infections are comparatively more difficult to control than wound invaders.

Quiescence of fungi in fruit has been implicated to constitutive (Karunanayake et al., 2011) or induced
(Adikaram et al., 1982) antifungal substances. Fruit losses due to postharvest fungal rots could be reduced if the infections could be kept in their quiescent phase for extended periods during storage and marketing. One possible way to prolong quiescence is to maintain the natural antifungal barrier present in the unripe fruit at an inhibitory level into the post-climacteric phase. Induction of natural resistance has been of considerable interest in the control of postharvest diseases for many years (Adikaram, 1990; Yang et al., 2007).

Resistance responses are triggered following the recognition of a range of biological, chemical or physical factors termed 'elicitors' (Terry \& Joyce, 2004). The identification of salicylic acid (SA) as a natural inducer of plant defense responses has prompted the characterization of synthetic chemicals that are able to mimic SA (Conrath et al., 1995). There is evidence of activation of defense responses due to exogenous application of SA in many fruit crops such as sweet cherry (Yao \& Tian, 2005; Bi et al. 2007), mango (Zeng et al., 2006) and pear (Tian et al., 2006). Acibenzolar-S-methyl ester $\left(\right.$ ASM, BTH, $\operatorname{Actigard}^{\circledR}$, Bion $^{\circledR}$ ), a functional analogue of SA, activates disease resistance in crops to a wide variety of pathogens (Hammerschmidt et al., 2001). The resistance induced in strawberry (Terry \& Joyce, 2000), peach (Liu et al., 2005), Yali pear (Cao et al., 2005) and pear (Tsiantos et al., 2003) has protected fruits from postharvest pathogens. Relatively little information is available on $\mathrm{K}_{2} \mathrm{HPO}_{4}$ as an elicitor of defenses in fruit crops. However, foliar sprays of phosphates $\left(\mathrm{K}_{2} \mathrm{HPO}_{4}\right.$ and $\mathrm{KH}_{2} \mathrm{PO}_{4}$ ) have been shown to control powdery mildew in field-grown nectarines, mango trees and grapevine

*Corresponding author (nkba@pdn.ac.lk) 
(Reuveni \& Reuveni, 1995) and also anthracnose disease in cashew (Lopez \& Lucas, 2002).

There is limited information on the resistance responses induced in banana fruit following fungal infection or treatment with chemical elicitors especially applied as preharvest treatments. The present study investigated the possibility of inducing resistance in banana fruit cv. 'Embul' against anthracnose disease, via pre-harvest application of chemical elicitors.

\section{METHODS AND MATERIALS}

\section{Banana plants}

Two-month old tissue cultured banana saplings cv. "Embul" of uniform size were planted in a field site at Meewatura, in the premises of the University of Peradeniya, Sri Lanka (longitudes 080 35' 42.3" east and latitudes $07^{\circ} 15^{\prime} 06.3$ " north). Planting pits $\left(2 \times 2 \times 2 \mathrm{ft}^{3}\right)$ were dug leaving a $3 \mathrm{~m}$ distance between rows and pits. Urea $(110 \mathrm{~g})$, muriate of potash (150 g) and rock phosphate $(190 \mathrm{~g})$ were applied to plants as recommended by the Department of Agriculture, 2, 5 and 9 months after planting. Plants were watered regularly and pesticides were not applied at any stage during the field trial.

\section{Chemical elicitor treatment}

Suspensions/solutions of Bion ${ }^{\circledR}$ (200 mg/L, acibenzolarS-methyl; Syngenta), salicylic acid (500 $\mathrm{mg} / \mathrm{L}$, $\mathrm{C}_{7} \mathrm{H}_{5} \mathrm{O}_{3} \mathrm{Na}$, Sigma $\left.{ }^{\circledR}\right)$ and $\mathrm{K}_{2} \mathrm{HPO}_{4}(20 \mathrm{mg} / \mathrm{L})$ were prepared in sterile distilled water. Tween $20(50 \mu \mathrm{L} / \mathrm{L})$ was added as a wetting agent. The elicitor concentration for treatment was decided from the results of preceding postharvest treatment trials (Wanigasekara, 2009). The treatments were arranged in a randomized complete block design within a factorial scheme (4 treatments $\times 2$ application times). The treatments were (i) Bion ${ }^{\circledR}$ (200 mg/L $500 \mathrm{mg} / \mathrm{L})$, (ii) salicylic acid (500 mg/L), (iii) $\mathrm{K}_{2} \mathrm{HPO}_{4}(20 \mathrm{mg} / \mathrm{L})$ and distilled water (control), applied at two stages (i) 2 and 4 weeks after bunch emergence (WABE), and (ii) 9 and 11 WABE. Banana bunches intact to the plant, were separately sprayed with chemical elicitor preparations or distilled water (control) using a domestic hand-held sprayer until run-off. Six replicate bunches were used per treatment.

\section{Harvesting}

Treated bunches were harvested $14-15$ weeks after bunch emergence and brought to the Plant Pathology Laboratory, Department of Botany, weighed and de- handed. The hands were washed in running tap water and allowed to dry. The number of hands and the weight of each hand were recorded. Ten fruits from the third hand of each bunch were weighed and the average fruit weight was calculated. Uniform sized fruits from the upper four hands without any defects were selected and used for inoculation experiments.

\section{Inoculation and disease assessment}

Colletotrichum musae isolated from an anthracnose lesion on a ripe banana fruit cv. "Embul", identified using the Commonwealth Mycological Institute (CMI) descriptions and maintained on potato dextrose agar at $26{ }^{\circ} \mathrm{C} \pm 2$, was used for all the experiments. A conidial suspension was obtained by flooding a 10 day - old culture with sterile distilled water (SDW) and scraping the mycelium. The suspension was filtered through glass wool and the concentration in the filtrate was adjusted to $1 \times 10^{6}$ conidia $\mathrm{mL}^{-1}$. Fifteen fruits from each treatment were wiped with cotton wool soaked with $70 \%$ ethanol and allowed to air-dry. The fruits were challenge inoculated by placing three drops $(20 \mu \mathrm{L})$ of a conidia suspension of $C$. musae along the long axis of each fruit. Inoculated fruits were incubated in moist chambers at $26{ }^{\circ} \mathrm{C} \pm 2$ for 10 days. The number of inoculations that developed into lesions was recorded daily and the percentage disease incidence was calculated. The diameter of lesions was measured at two positions right angles to each other and the average lesion area was calculated for each treatment. Percentage disease reduction in each treatment was calculated against controls.

\section{Induced defence responses}

Elicitor treated and control fruits from three replicate bunches were inoculated with $C$. musae on the day of harvest. Peel segments ( $1-2 \mathrm{~mm}$ thick, $15 \mathrm{~g})$ were cut from beneath the drop of inoculum immediately after inoculation and again after three days.

Chitinase activity was assayed by the method described by Zou et al. (2002) with slight modifications. One gram of the tissue sample was homogenized in $5 \mathrm{~mL}$ of $0.067 \mathrm{M}$ sodium phosphate buffer $(\mathrm{pH} 5)$ for 2 min, using an ultrasonic homogenizer (Ultra Turrax ${ }^{\circledR}$ T25 basic, IKA Labortechnik) at $11,000 \mathrm{rpm}$. The homogenate was clarified by centrifugation at $6000 \mathrm{~g}$ (Sigma $3 \mathrm{~K} 30$ Laboratory centrifuge) and $4{ }^{\circ} \mathrm{C}$ for $10 \mathrm{~min}$. The supernatant was used for the enzyme assay. Agaroseglycol chitin substrate was prepared (Trudel \& Asselin, $1989)$ and poured into petri dishes (11 cm diameter). Aliquots $(10 \mu \mathrm{L})$ of the extract or standard chitinase (from Serratia marscescens, Chitinase EC 3.2.1.14, Sigma) 
were added to wells ( $2 \mathrm{~mm}$ diameter) cut in the gel and the plates were incubated for $20-22 \mathrm{~h}$ at $26{ }^{\circ} \mathrm{C} \pm 2$. The gel plate was stained with $0.1 \%(\mathrm{w} / \mathrm{v})$ calcofluor dye (Fluorescent Brightner 28, Sigma) for $20 \mathrm{~min}$ and washed with SDW for $2 \mathrm{~h}$ in an orbital shaker (IKa-Vibrax-VXR). The hydrolyzed zones were visualized by placing the gel under UV light [Mineralight ${ }^{\circledR}$ Lamp (365 nm), model UV GEL-58; Chromato- VUE Cabinet, model cc-10] and the diameter of the darker hydrolyzed zones was recorded. Sample enzyme activity was determined using a regression equation obtained from chitinase standards.

For $\beta$-1,3-glucanase assay, peel samples ( $1 \mathrm{~g}$ ) were homogenized at $11,000 \mathrm{rpm}$ in a pre-cooled centrifuge tube with $1 \%(\mathrm{w} / \mathrm{w})$ polyvinyl polypyrrolidone and $5 \mathrm{~mL}$ potassium acetate buffer $(50 \mathrm{mM}, \mathrm{pH}$ 5), containing $1 \mathrm{mM}$ EDTA and $5 \mathrm{mM}$ reduced glutathione (Dann \& Deverall, 2000). The extracts were centrifuged at $9000 \mathrm{~g}$ for $5 \mathrm{~min}$ at $4{ }^{\circ} \mathrm{C}$ and the supernatant was used for the enzyme assay. Potassium acetate buffer $(1.6 \mathrm{~mL}, 10 \mathrm{mM}$, $\mathrm{pH} 5)$ and the crude extract $(0.4 \mathrm{~mL})$ were allowed to equilibrate to $30^{\circ} \mathrm{C}$ for $3 \mathrm{~min}$. The reaction was initiated by adding $0.4 \mathrm{~mL}$ of the substrate (Pachyman) suspension and was stopped after $10 \mathrm{~min}$ by adding $2.8 \mathrm{~mL}$ of $20 \%(\mathrm{w} / \mathrm{v})$ Tris. The tube was vortexed for $5 \mathrm{~min}$ and centrifuged at $9000 \mathrm{~g}$ for $3 \mathrm{~min}$. Aliquots $(3.0 \mathrm{~mL})$ of the supernatant were transferred to cuvettes (Optiglass Ltd., England) and the absorbance was measured at 610 $\mathrm{nm}$ against a blank containing the substrate devoid of enzyme extract, using a spectrophotometer (Cam Spec M302, Spectronic Camspec Ltd., UK). The enzyme activity was expressed as absorbance at $610 \mathrm{~nm}$. Both experiments were repeated.

Antifungal activity: Peel tissues (10 g) cut from the fruits treated with each elicitor and controls 3 days after inoculation with conidia of $C$. musae, were extracted separately in ethyl acetate $(50 \mathrm{~mL})$ under vacuum with constant magnetic stirring for $1 \mathrm{~h}$. The extract was filtered through Whatman No. 1 filter paper. The residue was subjected to repeated extraction thrice with fresh ethyl acetate and the extracts were pooled and evaporated to dryness in a rotary evaporator at $40{ }^{\circ} \mathrm{C}$ (Stuart RE 300, UK) (Adikaram \& Bandara, 1998). The crude residue was collected in $500 \mu \mathrm{L}$ of ethyl acetate. The extract $(100 \mu \mathrm{L})$ was spotted on a thin layer chromatography (TLC) plate coated with silica gel (Kieselgel $\mathrm{GF}_{254}, 13 \%$ $\left.\mathrm{CaSO}_{4}, \mathrm{BDH}\right)$. The plate was developed in chloroform: methanol $(95: 5 \mathrm{v} / \mathrm{v})$ and air-dried overnight. The plate was carefully sprayed with a suspension of conidia of C. cladosporioides in Czapek-Dox nutrient solution and incubated for $2-3$ days in a moist chamber at RT (26 ${ }^{\circ} \mathrm{C} \pm 2$ ). The size and $\mathrm{Rf}$ values of areas lacking mycelia growth were recorded (Klarman \& Stanford, 1968).
Previous studies (Abayasekara et al., 2013) have shown that there was no difference in the number and the size of antifungal zones between the TLC plates bioassayed with Cladosporium cladosporioides and C. musae.

\section{Postharvest quality of chemical elicitor treated fruits}

The postharvest quality was assessed when the harvested fruit reached table ripe stage. Six fingers from the third hand of six replicate bunches were used to determine the fruit firmness, percentage titratable acidity ( $\%$ TA) and total soluble solids (TSS). Fruit firmness was measured using a pocket penetrometer (Forestry Suppliers Inc., UK) at three points along the long axis of each fruit and the values were averaged. The pulp ( $30 \mathrm{~g}$ ) was homogenized in $90 \mathrm{~mL}$ of distilled water in a Waring blender (Christison Laboratory Blender, Germany) for $1 \mathrm{~min}$ at high speed. The homogenate was centrifuged at $3000 \mathrm{~g}$ for $5 \mathrm{~min}$ and filtered through a muslin cloth. A few drops of the filtrate was placed on a hand-held refractrometer (Leica, model 10430) and the reading was multiplied by the dilution factor $(\times 3)$ to obtain the TSS (Dadzie \& Orchard, 1997). A sample $(10 \mathrm{~mL})$ of the filtrate was titrated against $0.03 \mathrm{M} \mathrm{NaOH}$ with phenolphthalein as the indicator and $\%$ TA was calculated (Dadzie \& Orchard, 1997).

Fruit ripening: Four clusters each containing six banana fingers, removed from six replicate bunches were used for each treatment. The fruits were allowed to ripen at room temperature and the ripening was assessed daily using a colour index, 0 - green, 1 - colour-break, 2 - more greener than yellow, 3 - more yellow than green, 4 yellow with green tip and stalk, 5 - yellow (fully ripe), 6 - yellow with brown spotting (over ripe). Number of days taken to reach the colour-break stage after harvest was determined and used to compare the ripening of fruits subjected to different treatments.

\section{Test for any inhibitory effect of defence elicitors on the pathogen}

A series of solutions containing $0,10,25,400,1000$ and $2000 \mathrm{mg} / \mathrm{mL}$ of each elicitor was prepared. Equal quantities of elicitor solution and a conidia suspension $\left(10^{6}\right.$ conidia $\left./ \mathrm{mL}\right)$ of $C$. musae were mixed. Drops $(20 \mu \mathrm{L})$ were placed on clean glass slides ( 2 drops per slides and 2 slides per treatment). The slides were incubated in moist chambers at $26^{\circ} \mathrm{C} \pm 2$ and at the end of $8 \mathrm{~h}$ a drop of lactophenol was added to each drop to stop germination. One hundred randomly selected conidia from each drop were counted for germination under high power $(\times 400)$ light microscope and percentage germination for each elicitor concentration was determined. 


\section{Statistical analysis}

Fruit ripening data were analyzed by Kruskal Wallis test followed by mean separation by Mood Median $(p=0.05)$ test using MINITAB Release 13.1 and all the other data were analysed by ANOVA using general linear model (GLM) procedure. Means were separated by Duncan's multiple range test (DMRT) using SAS Release 6.12 and differences at $5 \%$ level were considered as significant.

\section{RESULTS}

Effect of pre-harvest elicitor application on postharvest anthracnose development in $C$. musae inoculated fruits

There was a greater and significant $(\mathrm{p}<0.05)$ reduction in anthracnose development in fruits when they were treated with Bion ${ }^{\circledR}$ or SA elicitor preparations at a later stage of fruit development ( 9 and 11 WABE) than at an early stage ( 2 and 4 WABE) (Table 1a). Two way ANOVA showed that there was a significant $(\mathrm{p}=0.0001)$ difference in disease severity between the two application times and among the three different chemical elicitors used. The interaction between the two factors, the application time and elicitor type, was significant $(\mathrm{p}=0.0001)$ (Table $1 \mathrm{~b})$. The fruits treated with Bion ${ }^{\circledR}$ or SA at 9 and 11 WABE stage showed delayed development and reduced severity of anthracnose lesions compared to the untreated controls (Table 2). Therefore the subsequent studies were carried out using the fruits treated at 9 and 11 WABE.

In SA treated fruits, the anthracnose lesions commenced one day later than in the fruits treated with Bion $^{\circledR}$. The lesions in SA treated fruits expanded much slower compared to Bion ${ }^{\circledR}$ treated fruits and the controls (Table 2). There were no anthracnose lesions in the fruits treated with salicylic acid until the $8^{\text {th }}$ day after inoculation while in the controls, the lesions could be seen on the $6^{\text {th }}$ day (Table 2). The lesions developed 9 and 10 days after inoculation in SA treated fruits were significantly $(p<0.05)$ smaller compared to that of the Bion $^{\circledR}$ treated fruits. Treatment with Bion ${ }^{\circledR}$ or SA at 9 and 11 WABE, while delaying the disease incidence, significantly reduced $(\mathrm{p}<0.05)$ the severity of the disease by $43 \%$ and $65 \%$, respectively compared to the control. SA $(500 \mathrm{mg} / \mathrm{L})$ treatment was $22 \%$ more effective than Bion $^{\circledR}(200 \mathrm{mg} / \mathrm{L})$ while the treatment with $\mathrm{K}_{2} \mathrm{HPO}_{4}$ $(20 \mathrm{mg} / \mathrm{L})$ increased the disease severity by $5 \%$. $\mathrm{K}_{2} \mathrm{HPO}_{4}$ treated fruits developed anthracnose lesions, which were similar in size to that of the controls until the $8^{\text {th }}$ day and increased in size thereafter. The disease incidence in fruits treated with Bion ${ }^{\circledR}$, SA or $\mathrm{K}_{2} \mathrm{HPO}_{4}$ was not, however, significantly different from that of the control (Table 2)

Table 1a: Development of anthracnose during ripening of fruits pre-treated with different elicitors at 2 and 4 weeks after bunch emergence (WABE) or 9 and 11 WABE, following inoculation with C. musae

\begin{tabular}{ccccc}
\hline Treatment stage & & Disease severity (lesion area, $\mathrm{cm}^{2} /$ fruit) & \\
& Bion $^{\circledR}$ & $\mathrm{SA}$ & $\mathrm{K}_{2} \mathrm{HPO}_{4}$ & Control (SDW) \\
\hline 2 and 4 weeks after bunch emergence & $0.64^{\mathrm{a}}\left(-23 \%^{*}\right)$ & $0.53^{\mathrm{a}}(-1.9 \%)$ & $0.74^{\mathrm{a}}(-42 \%)$ & $0.52^{\mathrm{a}}$ \\
9 and 11 weeks after bunch emergence & $0.23^{\mathrm{b}}(43 \%)$ & $0.14^{\mathrm{b}}(65 \%)$ & $0.42^{\mathrm{b}}(-5 \%)$ & $0.40^{\mathrm{a}}$ \\
\hline
\end{tabular}

* Percentage disease reduction

Means within each column followed by the same letter are not significantly different (DMRT, $\mathrm{p}<0.05$ )

Table 1b: Two-way ANOVA of disease severity data showing interaction effects among treatments

\begin{tabular}{lcrc}
\hline Source & df & \multicolumn{1}{c}{$\mathrm{F}$} & $\mathrm{p}$ \\
\hline Elicitor application time & 1 & 233.92 & 0.0001 \\
Elicitor & 3 & 16.84 & 0.0001 \\
Interaction & 3 & 13.58 & 0.0001
\end{tabular}

\section{Defense-related enzymes}

The fruits treated with Bion $^{\circledR}$ or SA upon challenge inoculation with $C$. musae after harvest showed a significant increase in chitinase activity on the $3^{\text {rd }}$ day (Figure 1a). The increase of chitinase activity in fruits treated with either elicitor three days after inoculation, was 10 fold compared to the controls. An increase in $\beta-1$, 
Table 2: Incidence and severity of anthracnose disease in fruit cv. "Embul" treated with elicitors at 9 and 11 weeks after bunch emergence, following artificially inoculation with C. musae after harvest

\begin{tabular}{|c|c|c|c|c|c|c|c|c|c|c|}
\hline \multirow[b]{3}{*}{ Treatment } & \multicolumn{5}{|c|}{ Disease severity (lesion area $\mathrm{cm}^{2} /$ fruit) } & \multicolumn{5}{|c|}{ Disease incidence $(\%)$} \\
\hline & \multicolumn{5}{|c|}{ Days after inoculation } & \multicolumn{5}{|c|}{ Days after inoculation } \\
\hline & $6 \mathrm{~d}$ & $7 \mathrm{~d}$ & $8 \mathrm{~d}$ & $9 \mathrm{~d}$ & $10 \mathrm{~d}$ & $6 \mathrm{~d}$ & $7 \mathrm{~d}$ & $8 \mathrm{~d}$ & $9 \mathrm{~d}$ & $10 \mathrm{~d}$ \\
\hline Bion ${ }^{\circledR}$ & $0.00^{\mathrm{b}}$ & $0.03^{b}$ & $0.19^{b}$ & $0.41^{\mathrm{c}}$ & $0.79^{c}$ & $0.00^{\mathrm{a}}$ & $13.3^{\mathrm{a}}$ & $65.4^{\mathrm{a}}$ & $65.4^{\mathrm{a}}$ & $89.4^{\mathrm{a}}$ \\
\hline SA & $0.00^{\mathrm{b}}$ & $0.00^{\mathrm{b}}$ & $0.13^{b}$ & $0.28^{\mathrm{d}}$ & $0.48^{\mathrm{d}}$ & $0.00^{\mathrm{a}}$ & $00.0^{\text {a }}$ & $66.6^{\mathrm{a}}$ & $70.6^{\mathrm{a}}$ & $96.0^{\mathrm{a}}$ \\
\hline $\mathrm{K}_{2} \mathrm{HPO}_{4}$ & $0.00^{\mathrm{b}}$ & $0.12^{\mathrm{a}}$ & $0.34^{\mathrm{a}}$ & $0.80^{\mathrm{a}}$ & $1.67^{\mathrm{a}}$ & $0.00^{\mathrm{a}}$ & $46.7^{\mathrm{a}}$ & $86.8^{\mathrm{a}}$ & $90.8^{a}$ & $98.6^{\mathrm{a}}$ \\
\hline$*$ Control & $0.03^{\mathrm{a}}$ & $0.12^{\mathrm{a}}$ & $0.39^{\mathrm{a}}$ & $0.65^{b}$ & $1.13^{b}$ & $6.66^{\mathrm{a}}$ & $24.0^{\mathrm{a}}$ & $94.8^{\mathrm{a}}$ & $94.8^{\mathrm{a}}$ & $96.0^{\mathrm{a}}$ \\
\hline
\end{tabular}

Means within each column followed by the same letters are not significantly different (DMRT, p $<0.05)$.

* Treated with SDW and inoculated after harvest with C. musae

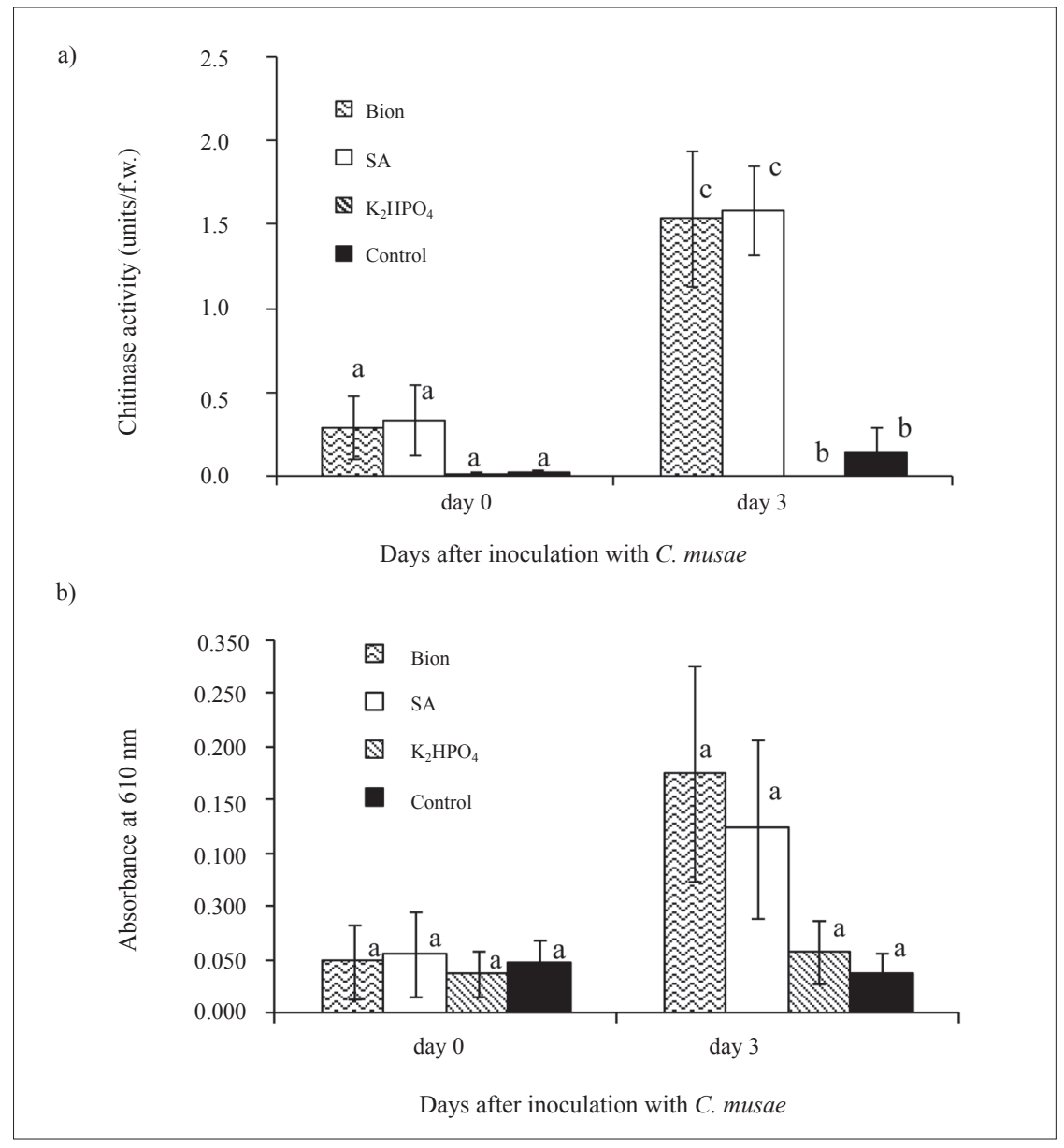

Figure 1: Chitinase (a) and B-1,3-glucanase (b) activity in the peel of banana treated with chemical elicitors 9 and 11 weeks after bunch emergence and challenge inoculated soon after harvest with $C$. musae. Columns with same letters, at each time point, are not significantly different (DMRT, $\mathrm{p}<0.05$ ). 
3-glucanase activity was also observed in treated fruits following inoculation, however, the increase was not significant (Figure 1b). $\mathrm{K}_{2} \mathrm{HPO}_{4}$ treatment did not induce defense related enzymes (Figure 1a \& b).

\section{Antifungal activity}

The extracts of peel tissues taken on the day of harvest from all treated and control fruits produced two slight antifungal areas at $R_{f} 0.80-0.90$ and $R_{f} 0.45-0.59$. The antifungal activity of these zones diminished after three days of inoculation and/ or harvest (Figure 2) to relatively less prominent antifungal areas. Three days after inoculation with $C$. musae, the fruits treated with Bion $^{\circledR}$ or SA showed two additional antifungal zones at $\mathrm{R}_{\mathrm{f}} 0.02-0.03$ and $\mathrm{R}_{\mathrm{f}} 0.51-0.71$. The latter was more prominent in SA treated fruit peel extract compared to that of the Bion ${ }^{\circledR}$ treated fruits.
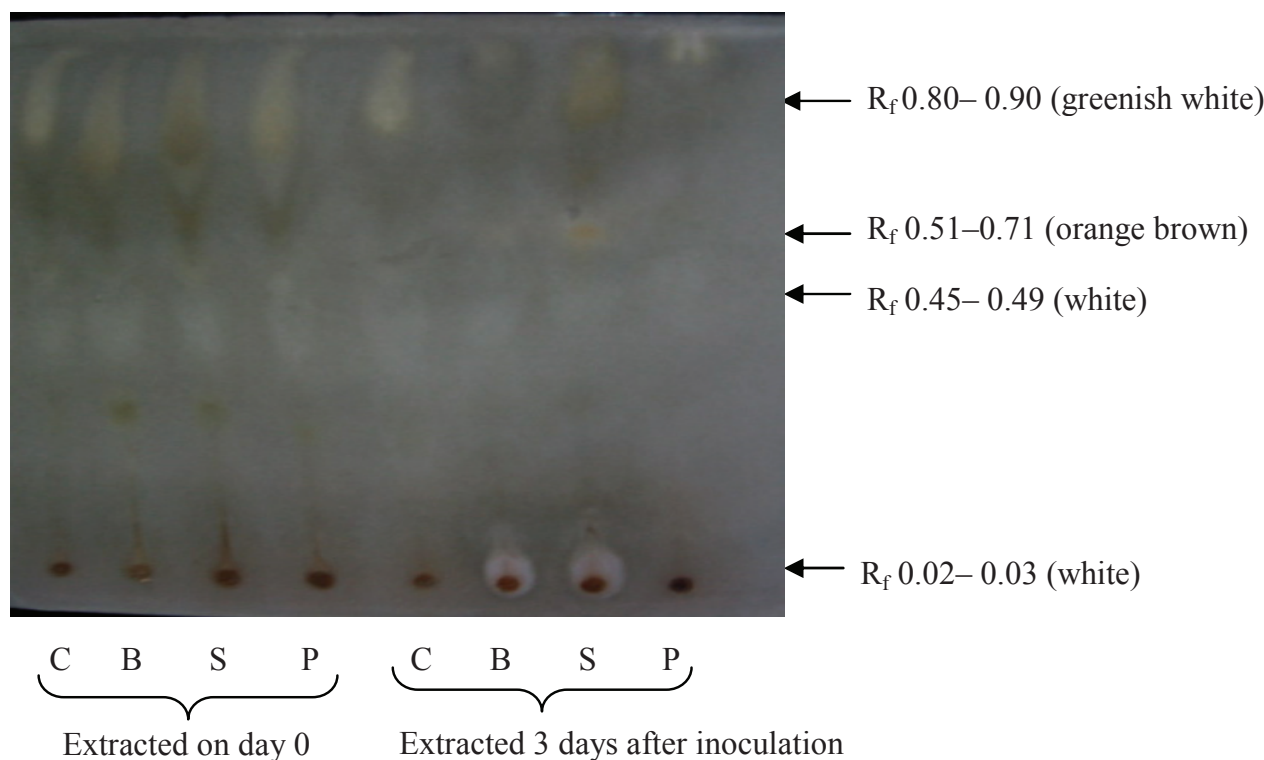

Figure 2: Thin layer chromatograph of peel extract of banana treated with elicitors, 9 and 11 weeks after bunch emergence, and inoculated soon after harvest with C. musae (developing solvent chloroform: methanol 95:5 v/v) bioassayed with $C$. cladosporioides. $\mathrm{C}=$ control, $\mathrm{B}=\mathrm{Bion}{ }^{\circledR}, \mathrm{S}=\mathrm{SA}, \mathrm{P}=\mathrm{K}_{2} \mathrm{HPO}_{4}$

Table 3: Postharvest quality of banana cv. 'Embul' treated with elicitors 9 and 11 weeks after bunch emergence after ripening

\begin{tabular}{lccccc}
\hline Treatment & $\begin{array}{c}\text { Average } \\
\text { fruit wt }(\mathrm{g})\end{array}$ & $\begin{array}{c}\text { Firmness } \\
\left(\mathrm{Kg} / \mathrm{cm}^{2}\right)\end{array}$ & $\begin{array}{c}\mathrm{TSS}^{\mathrm{y}} \\
\left({ }^{\circ} \mathrm{Brix}\right)\end{array}$ & $\begin{array}{c}\text { \% TA } \\
\text { yion }\end{array}$ & $\begin{array}{c}{ }^{\circledR} \text { Days to reach } \\
\text { colour break stage }\end{array}$ \\
$\mathrm{SA}$ & $112.7^{\mathrm{a}}$ & $1.21^{\mathrm{a}}$ & $17.0^{\mathrm{a}}$ & $0.71^{\mathrm{a}}$ & $* 5^{\mathrm{a}}$ \\
$\mathrm{K}_{2} \mathrm{HPO}_{4}$ & $86.8^{\mathrm{a}}$ & $1.40^{\mathrm{a}}$ & $16.3^{\mathrm{a}}$ & $0.74^{\mathrm{a}}$ & $6^{\mathrm{a}}$ \\
$*$ Control & $101.4^{\mathrm{a}}$ & $1.06^{\mathrm{a}}$ & $16.8^{\mathrm{a}}$ & $0.72^{\mathrm{a}}$ & $5^{\mathrm{a}}$ \\
\hline
\end{tabular}

${ }^{1}$ Assessed at table ripe stage (colour index 1)

${ }^{2}$ Colour index 1

Means within each column followed by the same letters are not significantly different (DMRT, $\mathrm{p}<0.05$ ). Each data point represents mean of six fingers from six replicate bunches.

* Devoid of elicitor treatment treated with SDW 


\section{Postharvest quality of elicitor-treated fruit at late fruit development stage}

There was no significant difference in the fruit weight between elicitor-treated and control (Table 3). The treatments neither had any apparent phytotoxic effect on fruits at harvest nor after ripening. The postharvest quality of treated fruits evaluated in terms of the change in fruit firmness, TSS and \% TA was not altered due to elicitor treatment. All parameters tested were not significantly different from those of the controls (Table 3 ).
Test for any inhibitory effect of elicitors on the pathogen

There was a slight reduction in the germination of conidia in both Bion ${ }^{\circledR}$ and SA, which is not, however, significant $(\mathrm{p}=0.05)$. In $\mathrm{K}_{2} \mathrm{HPO}_{4}$ the percentage germination reduced progressively with the increase of the concentration and there was no germination at $1000 \mathrm{mg} / \mathrm{L}$ (Table 4).

Table 4: Germination of conidia of C. musae in elicitor solutions at different concentrations

\begin{tabular}{|c|c|c|c|}
\hline \multirow[b]{2}{*}{ Concentration $(\mathrm{mg} / \mathrm{L})$} & \multicolumn{3}{|c|}{$\%$ germination of conidia } \\
\hline & Bion $^{\circledR}$ & SA & $\mathrm{K}_{2} \mathrm{HPO}_{4}$ \\
\hline 0 (control) & 21.5 & 21.5 & 21.5 \\
\hline 10 & 15.5 & 15.5 & 15.1 \\
\hline 25 & 16.7 & NA & 12.5 \\
\hline 400 & 22.2 & 13.2 & 10.0 \\
\hline 1000 & 12.5 & 14.1 & 0.0 \\
\hline 2000 & NA & 10.0 & 0.0 \\
\hline $\mathrm{p}$ & 0.497 & 0.226 & 0.003 \\
\hline z & -0.68 & -1.21 & -2.93 \\
\hline
\end{tabular}

NA - Not Assessed

$\mathrm{p}$ values and $\mathrm{z}$ values were calculated using binary logistic regression

\section{DISCUSSION}

Pre-harvest spray treatment of developing bananas with SA or Bion ${ }^{\circledR}$ delayed the incidence and reduced the severity of anthracnose disease in the harvested fruits during ripening. The treatment applied at a later stage of fruit development i.e. 9 and 11 weeks after bunch emergence ( 9 and $11 \mathrm{WABE}$ ) was found to be more effective. A similar treatment at an earlier stage of fruit development, 2 and 4 WABE, was less effective, indicating that the selection of an appropriate development stage of the fruit is crucial for the elicitor treatment to be effective. The data analysed by two-way ANOVA revealed that the type of chemical elicitor, time of their application and their interactions had a significant influence on the severity of anthracnose disease. The interaction was also evident from the outcome of the experiment where the application of elicitors at a late maturity stage had a greater effect on disease development than that of an early maturity stage. The timing of elicitor treatment and the selection of plant developmental stage have been important in determining the efficacy of Bion ${ }^{\circledR}$ treatment in strawberry against grey mould disease (Terry \& Joyce, 2004).

In the present study, the time interval between the elicitor treatment and pathogen challenge in bunches was shorter when the treatment was given 9 and 11 WABE compared to that of 2 and $4 \mathrm{WABE}$. The period between the application of elicitor and the induction of defence responses has been found to be rather short in herbaceous plants (Benhamou \& Bélanger, 1998). Of the elicitors used in the study, both Bion ${ }^{\circledR}$ and SA were effective while $\mathrm{K}_{2} \mathrm{HPO}_{4}$ treatment tended to increase the anthracnose severity. Neither the pre- nor postharvest application of potassium phophonate $(0.1-1.0 \mathrm{mg} / \mathrm{L})$ induced mango fruit resistance against $C$. gloeosporioides (Zainuri et al., 2001). However, there are reports of enhanced resistance obtained with phosphate salts in wine grapes (Reuveni \& Reuveni, 1995). This shows that all elicitors are not equally capable of inducing resistance in every fruit species and that the selection of an appropriate elicitor for treatment is vital. 
The treatment of developing banana fruits with SA or Bion $^{\circledR}$, while delaying the anthracnose development during ripening reduced the rate of expansion of lesions but did not totally control the disease. Plants induce resistance to pathogens when treated with a variety of biotic and abiotic inducers, yet the resistance induced rarely provides complete disease control with most inducing agents reducing the infection by $20-85 \%$ (Walters, 2009). Pre-harvest SA application has enhanced resistance in mango (Zainuri et al., 2001) and cherry (Yao \& Tian, 2005). Bion ${ }^{\circledR}$ has shown a good potential of eliciting resistance to postharvest diseases in melon (Huang et al., 2000) and peach (Liu et al., 2005).

$\mathrm{SA}$ or $\mathrm{Bion}^{\circledR}$ treatment induced greater chitinase and $\beta$-1,3-glucanase activity in harvested banana fruits when they were challenge inoculated with $C$. musae. The enhanced disease resistance observed during this study could at least in part be due to the induction of chitinase and $\beta$-1,3-glucanase. These enzymes can be directly antifungal to the invading pathogen by lysing fungal cell walls. Alternatively, the breakdown products of pathogen and/or plant cell wall components released by the activity of these enzymes can act as elicitors of plant defence responses (Van Loon, 1997). Increases in chitinase and glucanase have been common in other fruits such as tomato (Baysal et al., 2003), sweet cherry (Yao \& Tian, 2005) and cucumber (Alkahtani et al., 2011). In addition, the treatment with SA or Bion ${ }^{\circledR}$ in the present study showed accumulation of phytoalexins in the fruit peel. Phytoalexins too play a role in localized defense against fungal infections in plants. Brown and Swinburne (1980) demonstrated the accumulation of at least five phytoalexins in the peel tissue beneath the drops of conidia of $C$. musae applied on the surface of green bananas by using thin layer chromatography bioassay. Several phytoalexins were later chemically characterized from C. musae-infected banana fruit tissues (Kamo et al., 2001; Abayasekara et al., 2013).

These defense-related compounds were observed only after challenge inoculation of banana fruits with C. musae. The defense responses were assayed 3 days after inoculation of the fruit with $C$. musae, by which time the lesion initiation had just started as brown spots beneath the inoculation sites. Usually the treatment with a chemical elicitor does not necessarily produce apparent biochemical changes typical of systemic acquired resistance as long as the plant is not challenged with a pathogen. The elicitor treated plant is primed to react more efficiently than without the elicitor treatment (Gozzo, 2003).
The concentrations of elicitor solutions used in the treatment were only slightly inhibitory to C. musae. Bion $^{\circledR}$ has been developed as a novel crop protection agent, which does not itself have antimicrobial properties (Górlach et al., 1996). However, there have been contradictory observations regarding SA. Yao and Tian (2005) reported direct fungi toxicity in SA treated sweet cherry fruits against Monilinia fructicola, while Reglinski et al. (1997) stated that the reduction of Sclerotinia sclerotiorum infection in Kiwi fruit was attributed to the induction of host defense mechanisms.

Elicitor treatments had no apparent toxicity on fruits at harvest. There was no significant difference in fruit weight between the control and the elicitor treatments. However, Lopez and Lucas (2002) noted phytotoxicity when cashew leaves were sprayed with $0.3 \mathrm{mM}$ ASM. It has been reported that SA was phytotoxic when applied as a pre-harvest spray and caused injury at leaf margins where the runoff accumulates (Reglinski et al., 1997). The application of chemical elicitors often provides adverse effects on the crop yield. Although bell pepper plants sprayed with the chemical acibenzolar-S-methyl showed resistance to subsequent infections by Xanthomonas axonopodis pv. Vesicatoria, the treatment resulted in an unpredictable loss in fruit yield (Romero et al., 2001). The elicitors tested in the current study did not adversely affect fruit ripening or any other physicochemical parameter of the banana fruit.

In conclusion the present study has shown that SA or Bion ${ }^{\circledR}$ treatment, given at a late fruit development stage in the field enhanced resistance of harvested fruits when challenge inoculated with $C$. musae, reducing anthracnose development without altering the postharvest fruit quality.

\section{Acknowledgement}

Authors gratefully acknowledge the Australian Centre for International Agricultural Research (ACIAR), Australia for financial support.

\section{REFERENCES}

1. Abayasekara C.L., Adikaram N.K.B., Wanigasekara U.W.N.P. \& Bandara B.M.R. (2013). Phyllosticta musarum infection-induced defences suppress anthracnose disease caused by Colletotrichum musae in banana fruits $\mathrm{cv}$ 'Embul'. Plant Pathology Journal 29(1): 77 - 86. DOI: http://dx.doi.org/10.5423/PPJ.OA.06.2012.0081 
2. Adikaram N.K.B. (1990). Possibility of control of postharvest fungal diseases by manipulation of host defence systems. Proceedings of the $3^{\text {rd }}$ Conference on Plant Protection in the Tropics, volume 5, Genting Highlands, Malaysia, pp. $31-36$.

3. Adikaram N.K.B., Brown A.E. \& Swinburne T.R. (1982). Phytoalexin involvement in the latent infection of Capsicum annuит L. fruit by Glomerella cingulata (stonem.). Physiological Plant Pathology 21: 161 - 170.

4. Adikaram N.K.B. \& Bandara B.M.R. (1998). Methodology for studying defense mechanisms against fungal pathogensan overview. In: Disease Resistance in Fruits (eds. G.I. Johnson, E. Highley \& D.C. Joyce), ACIAR Proceedings No. 80, Queensland, Australia, pp. 177 - 185.

5. Alkahtani M., Omer S.A., El-Naggar M.A., Abdel Kareem E.M. \& Mahmoud M.A. (2011). Pathogenesis-related proteins and phytoalexin induction against cucumber powdery mildew by elicitors. International Journal of Plant Pathology 2(2): 63 - 71.

DOI: http://dx.doi.org/10.3923/ijpp.2011.63.71

6. Baysal Ö., Soylu E.M. \& Soylu S. (2003). Induction of defence-related enzymes and resistance by the plant activator acibenzolar-s-methyl in tomato seedlings against bacterial canker caused by Clavibacter michiganensis sp. Michiganensis. Plant Pathology 52: 747 - 753.

DOI: http://dx.doi.org/10.1111/j.1365-3059.2003.00936.x

7. Benhamou N. \& Bélanger R.R. (1998). Benzothiadiazolemediated induced resistance to Fusarium oxysporum $f$. $s p$. radicis-lycopersici in tomato. Plant Physiology 118: 1203 $-1212$.

DOI: http://dx.doi.org/10.1104/pp.118.4.1203

8. Bi Y., Li Y. \& Ge Y. (2007). Induced resistance in postharvest fruits and vegetables by chemicals and its mechanism. Stewart Postharvest Review 3: 1 - 7 . DOI: http://dx.doi.org/10.2212/spr.2007.6.1

9. Brown A.E. \& Swinburne T.R. (1980). The resistance of immature banana fruits to anthracnose [Colletotrichum musae (Berk. \& Curt.)Arx.]. Phytopathologisch Zeitschrift 99: $70-80$.

DOI: http://dx.doi.org/10.1111/j.1439-0434.1980.tb03762.x

10. Cao J., Jiang W. \& He H. (2005). Induced resistance in Yali pear (Pyrus bretschneideri Rehd.) fruit against infection by Penicillium expansum by postharvest infiltration of acibenzolar-S-methyl. Journal of Phytopathology 153: 640 -646 .

DOI: http://dx.doi.org/10.1111/j.1439-0434.2005.01031.x

11. Conrath U., Chen Z., Ricigliano J.R. \& Klessig D.F. (1995). Two inducers of plant defense responses, 2,6dichloroisonicotinic acid and salicylic acid, inhibit catalase activity in tobacco. Proceedings of the National Academy of Science, USA 92: 7143 - 7147.

DOI: http://dx.doi.org/10.1073/pnas.92.16.7143

12. Dadzie B.K. \& Orchard J.E. (1997). Routine postharvest screening of banana/plantain hybrids: criteria and methods. INIBAP Technical Guidelines 2, pp. 63. Biodiversity International, Montpellier, France.
13. Dann E.K. \& Deverall B.J. (2000). Activation of systemic acquired resistance in pea by an avirulent bacterium or a benzothiadiazole, but not by a fungal leaf spot pathogen. Plant Pathology 49: $324-332$.

DOI: http://dx.doi.org/10.1046/j.1365-3059.2000.00457.x

14. Görlach J. et al. (11 authors) (1996). Benzothiadiazole, a novel class of inducers of systemic acquired resistance, activates gene expression and disease resistance in wheat. The Plant Cell 8: $629-643$.

15. Gozzo F. (2003). Systemic acquired resistance in crop protection: from nature to a chemical approach. Journal of Agricultural and Food Chemistry 51(16): 4487 - 4503.

DOI: http://dx.doi.org/10.1021/jf030025s

16. Hammerschmidt R., Métraux J.P. \& Van Loon L.C. (2001). Inducing resistance: a summary of papers presented at the First International Symposium on Induced Resistance to Plant Diseases. Corfu, May 2000. European Journal of Plant Pathology 107: $1-6$. DOI: http://dx.doi.org/10.1023/A:1008753630626

17. Huang Y., Deverall B.J., Tang W.H., Wang W. \& Wu F.W. (2000). Foliar application of acibenzolar-s-methyl and protection of postharvest rock melons and 'hami' melons from disease. European Journal of Plant Pathology 106: $651-656$.

DOI: http://dx.doi.org/10.1023/A:1008767719691

18. Kamo T., Hirai N., Iwami K., Fujioka D. \& Ohigashi H. (2001). New phenylphenalenones from banana fruit. Tetrahedron 57: $7649-7656$.

19. Karunanayake L.C., Adikaram N.K.B., Abayasekara C.L., Kumarihamy B.M.M. \& Ratnayake Bandara B.M. (2011). Role of antifungal gallotannins, resorcinols and chitinases in the constitutive defense of immature mango (Mangifera indica L.). Journal of Phytopathology 159: 657 - 664. DOI: http://dx.doi.org/10.1111/j.1439-0434.2011.01818.x

20. Klarman W.L. \& Stanford J.L. (1968). Isolation and purification of an antifungal principle from infected soya beans. Life Sciences 7: 1095 - 1103.

21. Liu H., Jiang W., Bi B. \& Luo Y. (2005). Postharvest BTH treatment induces resistance of peach (Prunus persica L. cv. Jiubao) fruit to infection by Penicillium expansum and enhances activity of fruit defense mechanisms. Postharvest Biology and Technology 35(3): $263-269$.

DOI: http://dx.doi.org/10.1016/j.postharvbio.2004.08.006

22. Lopez A.M.Q. \& Lucas J.A. (2002). Effects of plant defense activators on anthracnose disease of cashew. European Journal of Plant Pathology 108: 409 - 420.

DOI: http://dx.doi.org/10.1023/A:1016010710703

23. Reglinski T., Poole P.R., Whitaker G. \& Hoyte S.M. (1997). Induced resistance against Sclerotinia sclerotiorum in kiwi fruit leaves. Plant Pathology 46: 716 - 721.

DOI: http://dx.doi.org/10.1046/j.1365-3059.1997.d01-50.x

24. Reuveni M. \& Reuveni R. (1995). Efficacy of foliar application of phosphates in controlling powdery mildew fungus on field grown wine grapes: effect on cluster yield and peroxidase activity in berries. Journal of Phytopathology 143: $21-25$. 
25. Romero A.M., Kousik C.S. \& Ritchie D.F. (2001). Resistance to bacterial spot in bell pepper induced by acibenzolar-s-methyl. Plant Disease 85: 189 - 194. DOI: http://dx.doi.org/10.1094/PDIS.2001.85.2.189

26. Swinburne T.R. (1983). Quiescent infections in post-harvest diseases. Postharvest Pathology of Fruits and Vegetables (ed. C. Dennis), pp. 1 - 21. Academic Press, London, UK.

27. Terry L.A. \& Joyce D.C. (2000). Suppression of grey mould on strawberry fruit with the chemical plant activator, acibenzolar. Pest Management Science 56: 989 - 992.

28. Terry L.A. \& Joyce D.C. (2004). Elicitors of induced disease resistance in postharvest horticultural crops: a brief review. Postharvest Biology and Technology 32: 1 - 13. DOI: http://dx.doi.org/10.1016/j.postharvbio.2003.09.016

29. Tian S., Wan Y., Qin G. \& Xu Y. (2006). Induction of defense responses against Alternaria rot by different elicitors in harvested pear fruit. Applied Microbiology and Biotechnology 70: $729-734$.

DOI: http://dx.doi.org/10.1007/s00253-005-0125-4

30. Trudel J. \& Asselin A. (1989). Detection of chitinase activity after polyacrylamide gel electrophoresis. Analytical Biochemistry 178: 362 - 366 .

31. Tsiantos J., Psallidas P. \& Chatzaki A. (2003). Efficacy of alternatives to antibiotic chemicals for the control of fire blight of pears. Annals of Applied Biology 143: $319-323$.

32. Van Loon L.C. (1997). Induced resistance in plants and the role of pathogenesis related proteins. European Journal of Plant Physiology 103: $753-765$.

33. Walters D.R. (2009). Are plants in the field already induced? Implications for practical disease control. Crop Protection
28(6): $459-465$.

DOI: http://dx.doi.org/10.1016/j.cropro.2009.01.009

34. Wanigasekara U.W.N.P. (2009). Biological and chemical elicitors of banana fruit defence. Ph. D. thesis, University of Peradeniya, Sri Lanka.

35. Yang B., Yongcai L. \& Yonghong G. (2007). Induced resistance in postharvest fruits and vegetables by chemicals and its mechanism. Stewart Postharvest Review 3(6): 1 - 7 . DOI: http://dx.doi.org/10.2212/spr.2007.6.1

36. Yao H. \& Tian S. (2005). Effects of pre-and post-harvest application of salicylic acid or methyl jasmonate on inducing disease resistance of sweet cherry fruit in storage. Postharvest Biology and Technology 35: 253 - 262. DOI: http://dx.doi.org/10.1016/j.postharvbio.2004.09.001

37. Zainuri Joyce, D.C., Wearing H., Coates L. \& Terry L.A. (2001). Effect of phosphonate and salicylic acid treatments on the disease development and ripening of "Kensington Pride" mango fruit. Australian Journal of Experimental Agriculture 41: 805 - 813.

DOI: http://dx.doi.org/10.1071/EA99104

38. Zeng K., Cao J. \& Jiang W. (2006). Enhancing disease resistance in harvested mango (Mangifera indica $1 . \mathrm{cv}$. 'Matisu') fruit by salicylic acid. Journal of the Science of Food and Agriculture 86: 694 - 698.

DOI: http://dx.doi.org/10.1002/jsfa.2397

39. Zou X., Nonogaki H. \& Welbaum G.E. (2002). A gel diffusion assay for visualization and quantification of chitinase activity. Molecular Biotechnology 22: 19-23. DOI: http://dx.doi.org/10.1385/MB:22:1:019 